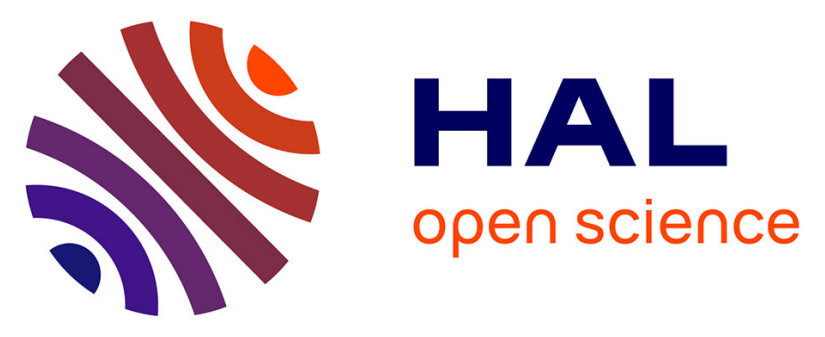

\title{
Design of a Mixed-Reality Serious Game to Tackle a Public Health Problem
}

\author{
Tiago França Melo Lima, João Paulo Ferreira Beltrame, Carlos Ramos \\ Niquini, Breno Gonçalves Barbosa, Clodoveu Augusto Davis
}

\section{- To cite this version:}

Tiago França Melo Lima, João Paulo Ferreira Beltrame, Carlos Ramos Niquini, Breno Gonçalves Barbosa, Clodoveu Augusto Davis. Design of a Mixed-Reality Serious Game to Tackle a Public Health Problem. Esteban Clua; Licinio Roque; Artur Lugmayr; Pauliina Tuomi. 17th International Conference on Entertainment Computing (ICEC), Sep 2018, Poznan, Poland. Springer International Publishing, Lecture Notes in Computer Science, LNCS-11112, pp.305-309, 2018, Entertainment Computing - ICEC 2018. 10.1007/978-3-319-99426-0_35 . hal-02128602

\section{HAL Id: hal-02128602 \\ https://hal.inria.fr/hal-02128602}

Submitted on 14 May 2019

HAL is a multi-disciplinary open access archive for the deposit and dissemination of scientific research documents, whether they are published or not. The documents may come from teaching and research institutions in France or abroad, or from public or private research centers.
L'archive ouverte pluridisciplinaire HAL, est destinée au dépôt et à la diffusion de documents scientifiques de niveau recherche, publiés ou non, émanant des établissements d'enseignement et de recherche français ou étrangers, des laboratoires publics ou privés.

\section{(c)(1)}

Distributed under a Creative Commons Attribution| 4.0 International License 


\title{
Design of a mixed-reality serious game to tackle a public health problem *
}

\author{
Tiago França Melo Lima ${ }^{1,2}[0000-0003-1319-8530]$, João Paulo Ferreira \\ Beltrame $^{1}$, Carlos Ramos Niquini ${ }^{1}$, Breno Gonalves Barbosa ${ }^{1}$, and Clodoveu \\ Augusto Davis Jr. ${ }^{2[0000-0002-7327-848 X]}$ \\ 1 Federal University of Ouro Preto (UFOP), João Monlevade - MG, Brazil. \\ 2 Computer Science Department - Federal University of Minas Gerais, Belo \\ Horizonte - MG, Brazil. \\ tiagolima@decsi.ufop.br, clodoveu@dcc.ufmg.br
}

\begin{abstract}
Despite the emergence of several game-based initiatives in health, aiming to train students and professionals and to support patients rehabilitation, some public health problems remains neglected. Mosquitoborne diseases are a global public health concern. Education and awareness of population are an important intervention strategy and should be part of public health policies, given that individuals' behavior may affect the transmission dynamics of diseases. For instance, improper storage of water can become a breeding site for the Aedes aegypti mosquito, the vector of dengue, zika, chikungunya and urban yellow fever viruses. Most of Aedes foci are in or near people's homes and the control of mosquitoes population is essential to prevent these diseases. We believe that games are a powerful tool and can be used to support awareness and behavioral changes regarding public health issues. This paper presents the current development stage of a serious game designed to support actions based on education and engagement of population aimed at vector surveillance and control. A mix of a $2 \mathrm{D}$ game with augmented and virtual reality modules and the real world itself will provide the proper environment to offer fun with the purpose of helping to deal with this complex problem. The development is based on agile principles, with short cycles involving activities of conception, design, construction and evaluation. Some partial results are game design, prototypes and demos. Future work includes designing and conducting an experimental study to evaluate effectiveness and efficiency regarding knowledge acquiring and behavioral changes.
\end{abstract}

Keywords: Serious games · Dengue $\cdot$ Aedes aegypti $\cdot$ Awareness $\cdot$ Education · Public health · Gamification.

\section{Introduction}

Powerful tools to face some real-world problems, approaches based on games have been applied in different areas and contexts for varied purposes. An example is gamification - the use of game design elements in a non-game context [3]

* The authors acknowledge the support from CNPq, FAPEMIG, IFIP Digital Equity Committee and UFOP. 
to achieve motivation and engagement [4]. Another example are serious games - those in which the primary purpose is other than offering fun and entertainment [9]. For instance, they can be designed to promote learning and behavioral changes $[2,5,9]$. Education and health are popular subjects for serious games. However, more specific but also important themes such as public health and mosquito-borne diseases remain neglected.

Dengue is a mosquito-borne viral disease and a global public health concern. Its primary vector is the Aedes aegypti mosquito, which also transmits chikungunya, yellow fever and zika viruses. Human behavior can contribute to the growth of vector population [10], and consequently, to the spread of diseases. For instance, improper stocks of water and inappropriate disposal of solid waste can become vector breeding sites. Thereby, citizens have an important role and must be included in public health policies to prevent and control dengue $[8,11]$.

Population awareness is generally based on traditional media advertisement and educational campaigns (e.g. classes, talks, theater) in schools and public places $[7,1]$. Game-based approaches are powerful tools to support education, awareness, engagement and behavior changes $[5,12,2]$. In this context, serious games and gamification could also be used to enhance the outcomes of educationbased policies for public health. In this project, we propose a serious game to support education and awareness about dengue, which can be used as an alternative strategy to assist vector surveillance and control.

\section{Development and results}

Research and game development activities were performed. A survey and analysis of serious games aimed at the areas of public health, vector-borne diseases, and more specifically, related to dengue was conducted. However, few examples of games were found. The game development process is based on agile principles, with short cycles (biweekly) involving conceiving, designing, building and evaluating prototypes or versions of the game. Some partial results are the game design document (GDD), low and high fidelity prototypes and the release of two demos - a 2D game with an augmented reality module and a virtual reality module, which can be played with a Google Cardboard. Some improvements are required before conducting an experimental study to evaluate the game.

\subsection{X-Dengue: Game Design}

The story is centered on the character Pedrinho, who decides to stop dengue because his best friend became ill and could no longer play with him. The game $\mathrm{X}$-Dengue [6] is organized into four modules (Fig. 1.1). The player's level of comprehension increases with each module. Initially, he will play in his home, directly against adult mosquitoes, using resources such as his hands and electric rackets. Vector breeding sites must also be eliminated to prevent the emergence of new mosquitoes. Over time, the player will realize that actions isolated and 


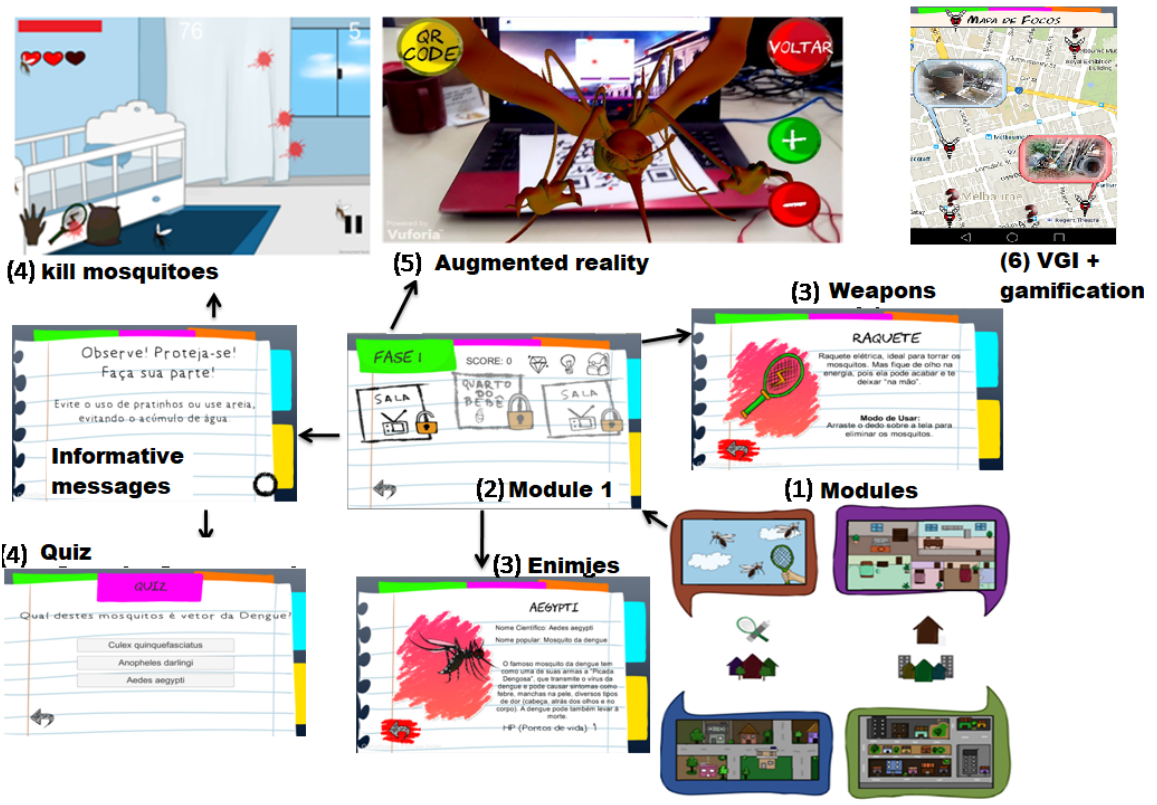

Fig. 1. Overview of the 2D-game modules and main features

restricted to his house are not effective. Thereby, he should extend his activities to the neighborhood (modules 2 and 3), and then to the whole city (module 4).

A demo version (module 1) was developed and tested with some users. In it, each phase consists of a set of rooms (Fig. 1.2). Some playful (fictitious) and realistic (scientifically grounded) information are available to players, about mosquitoes ("enemies") and weapons (Fig. 1.3). The player must fight adult mosquitoes and also eliminate breeding sites (Fig. 1.4). Phases have different types of objectives, such as to kill some mosquitoes, eliminate breeding sites, close windows to avoid entry of mosquitoes, use bed nets or repellents for protection. Messages about preventive actions and challenges (e.g. quiz) (Fig. 1 .4) are also present in the game design. An augmented reality module (Fig. 1.5 ) allows interaction with 3D models of the vector in each phase of its life cycle.

An innovative aspect proposed is the interaction between the virtual world (the game) and the real world to promote engagement and support vector surveillance. For instance, players will be invited to perform actions in the real world, such as taking pictures of places that can become mosquito breeding sites and attend educational campaigns. Thereby, the game may be used to support public health as an additional surveillance tool, to the extent that it will allow mapping places that need attention using a crowdsourcing strategy (Fig. 1 .6). Moreover, it can also help with dissemination and monitoring of educative campaigns. A VR module offers an immersive experience, where players may face dengue in a 3D environment and can interact with realistic models of Ae. aegypti. 


\section{Final remarks}

Games for health is an emergent research area. There are many efforts aimed towards training health students and professionals, and at the rehabilitation of patients. However, there is a significant shortage of initiatives that address global public health problems such as mosquito-borne diseases. The costs of mosquito-borne diseases are very high, and considerable resources are used to promote awareness, but usually involve simple advertisements on traditional media. Part of these resources should be used to conduct scientific research aiming to develop and evaluate the application of game-based methods to tackle public health complex problems, such as mosquito-borne diseases. The outcomes could be replicated and scaled to large populations. This study is part of an ongoing project. Future work includes 1) to perform a formal evaluation of the game (gameplay, usability and user experience); 2) to design and conduct an empirical study to assess its effectiveness.

\section{References}

1. Claro, L., Barreto, L., Kawa, H., Tricai Cavalini, L., Garcia Rosa, M.L.: Community Participation in Dengue Control in Brazil. Dengue Bulletin 30 (2006)

2. Connolly, T.M., Boyle, E.A., MacArthur, E., Hainey, T., Boyle, J.M.: A systematic literature review of empirical evidence on computer games and serious games. Computers \& Education 59(2), 661-686 (2012)

3. Deterding, S., Dixon, D., Khaled, R., Nacke, L.: From game design elements to gamefulness: defining gamification. In: Proc. 15th international academic MindTrek conference: Envisioning future media environments. pp. 9-15. ACM (2011)

4. Domínguez, A., de Navarrete, J.S., De-Marcos, L., Fernández-Sanz, L., Pagés, C., Martínez-Herráiz, J.J.: Gamifying learning experiences: Practical implications and outcomes. Computers \& Education 63, 380-392 (2013)

5. Dondlinger, M.J.: Educational video game design: A review of the literature. Journal of applied educational technology 4(1), 21-31 (2007)

6. Lima, T., Barbosa, B., Niquini, C., Araújo, C., Lana, R.: Playing against dengue. In: Serious Games and Applications for Health (SeGAH), 2017 IEEE 5th International Conference on. pp. 1-8. IEEE (2017)

7. Luna, J., Chain, I., Hernandez, J., Clark, G., Bueno, A., Escalante, R., Angarita, S., Martinez, A.: Social mobilization using strategies of education and communication to prevent dengue fever in Bucaramanga, Colombia. Dengue Bulletin (2004)

8. Madeira, N.G., Macharelli, C.A., Pedras, J.F., Delfino, M.C.: Education in primary school as a strategy to control dengue. Revista da Sociedade Brasileira de Medicina Tropical 35(3), 221-226 (2002)

9. Michael, D.R., Chen, S.L.: Serious games: Games that educate, train, and inform. Muska \& Lipman/Premier-Trade (2005)

10. Padmanabha, H., Soto, E., Mosquera, M., Lord, C., Lounibos, L.: Ecological links between water storage behaviors and aedes aegypti production: implications for dengue vector control in variable climates. Ecohealth 7(1), 78-90 (2010)

11. Pai, H.H., Yu-Jue, H., Hsu, E.L.: Impact of a short-term community-based cleanliness campaign on the sources of dengue vectors: an entomological and human behavior study. Journal of environmental health 68(6), 35 (2006)

12. Prensky, M.: Don't bother me, Mom, I'm learning! St. Paul: Paragon House (2006) 